\title{
Health service use and costs associated with aggressiveness or agitation and containment in adult psychiatric care: a systematic review of the evidence
}

\author{
Maria Rubio-Valera ${ }^{1,2,3,8^{*}}$, Juan V Luciano ${ }^{1,2,4}$, José Miguel Ortiz ${ }^{5}$ Luis Salvador-Carulla ${ }^{6}$, Alfredo Gracia ${ }^{7}$ \\ and Antoni Serrano-Blanco ${ }^{2,5}$
}

\begin{abstract}
Background: Agitation and containment are frequent in psychiatric care but little is known about their costs. The aim was to evaluate the use of services and costs related to agitation and containment of adult patients admitted to a psychiatric hospital or emergency service.

Methods: Systematic searches of four electronic databases covering the period January 1998-January 2014 were conducted. Manual searches were also performed. Paper selection and data extraction were performed in duplicate. Cost data were converted to euros in 2014.

Results: Ten studies met inclusion criteria and were included in the analysis (retrospective cohorts, prospective cohorts and cost-of-illness studies). Evaluated in these studies were length of stay, readmission rates and medication. Eight studies assessed the impact of agitation on the length of stay and six showed that it was associated with longer stays. Four studies examined the impact of agitation on readmission and a statistically significant increase in the probability of readmission of agitated patients was observed. Two studies evaluated medication. One study showed that the mean medication dose was higher in agitated patients and the other found higher costs of treatment compared with non-agitated patients in the unadjusted analysis. One study estimated the costs of conflict and containment incurred in acute inpatient psychiatric care in the UK. The estimation for the year 2014 of total annual cost per ward for all conflict was €182,616 and €267,069 for containment based on updated costs from 2005.

Conclusions: Agitation has an effect on healthcare use and costs in terms of longer length of stay, more readmissions and higher drug use. Evidence is scarce and further research is needed to estimate the burden of agitation and containment from the perspective of hospitals and the healthcare system.
\end{abstract}

Keywords: Aggression, Agitation, Containment, Costs, Health services research, Inpatients, Acute psychiatric wards, Review

\section{Background}

Although there is no universally accepted definition, agitation can be defined as a state of motor restlessness accompanied by mental tension that can be present in medical and psychiatric disorders (e.g., schizophrenia, bipolar disorder, Alzheimer's disease) [1] or emerge as a

\footnotetext{
*Correspondence: mrubio@pssjd.org

${ }^{1}$ Fundació Sant Joan de Déu, Esplugues de Llobregat, Spain

2Primary Care Prevention and Health Promotion Research Network (RedIAPP), Barcelona, Spain

Full list of author information is available at the end of the article
}

stand-alone behavioral problem. It is considered a frequent psychiatric emergency that presents across a wide clinical spectrum: it can evolve from mild psychomotor restlessness and mental tension to overt disruptive, aggressive or violent behavior. Approximately $30 \%$ of patients with a first psychotic episode who attend psychiatric services show risk of self-harm or other aggressive behavior [2]. Disturbed or violent behavior in patients in adult inpatient psychiatric units can affect their own safety, that of other patients, and staff. An NHS survey covering 1998/1999 found that there were

\section{Ciomed Central}


approximately 65,000 violent incidents against staff across the National Health Service in the UK. The average number of incidents in mental health/learning disability trusts was over three times the average for all trusts [3].

Restraint, seclusion, coercion and containment are frequent health care interventions in psychiatric in-patient settings to manage agitation with disruptive, aggressive or violent behavior $[4,5]$. In spite of their importance, these clinical actions have received very little attention in the available classifications of health interventions such as the Australian Mental Health Intervention Classification [6] or The Current Procedural Terminology code in the U.S. [7]. "Seclusion" has been defined as "the placement and retention of an inpatient in a bare room to contain a clinical situation that may result in a state of emergency" [4]. "Restraint" interventions are designed to "confine a patient's bodily movements" and there are two main subtypes: "physical", when staff members restrict and hold the patient manually, or "mechanical"; the use of belts, handcuffs, etc., that restrict the patient's movements [4]. "Containment" is a broader term that includes a wide variety of strategies including pharmacological treatment or non-pharmacological interventions or techniques such as increased observation levels, locked wards, de-escalation techniques, use of behavioral agreements or increased staffing levels [5].

Regarding the frequency with which these techniques are used, Stewart and colleagues [8] reviewed 45 studies performed in psychiatric services and observed that there was an average of up to five episodes of restraint per month in wards. The duration of the restraint episodes was about 10 minutes and the factors associated with a greater probability of restraint were: being male, young, and subject to compulsory or involuntary admission. Another review [9] showed great differences between 12 European countries in the type, frequency and duration of containment measures used, with the Netherlands and the UK at either end of the range. For example, a seclusion episode lasts for about 300 hours and mechanical restraint episodes last nearly 1,200 hours on average in the Netherlands; whereas in the UK, seclusion is very infrequent, mechanical restraint is forbidden, and physical restraint lasts considerably less than 30 minutes on average [9]. The EUNOMIA project [10], to date the most extensive study of coercion carried out in European psychiatric inpatient facilities, revealed that the percentage of patients receiving coercive measures (physical restraint, seclusion, and forced medication) in each participating country varied from $21 \%$ to $59 \%$. The frequency of use of these measures depended on diagnosis and illness severity but was considerably influenced by the societal attitudes and clinical traditions of each country.
Some systematic reviews have examined the effectiveness of restraint, seclusion, and containment strategies [4,5,11]. Surprisingly, a Cochrane review by Sailas and Fenton [4] pointed out that "No controlled studies exist that evaluate the value of seclusion or restraint in those with serious mental illness". Therefore, no recommendation could be made about the effectiveness, benefit or harmfulness of seclusion or restraint based on scientific evidence. Of the 6 studies reviewed by Muralidharan and Fenton [5], none focused on non-pharmacological methods for containment of aggression or self-harm in people with serious mental illness. Thus, nonpharmacological containment strategies for patients exhibiting disturbed or violent behavior are not supported by evidence from controlled studies. Kynoch et al. [11] reviewed ten studies that evaluated the effectiveness of interventions for preventing and managing aggressive patients in acute hospital settings. The most common interventions for managing aggressive conduct in acute care settings were: staff education programs, chemical restraint and mechanical restraint. Although the three strategies showed some degree of effectiveness, the first was preferred by the authors because it sensitizes staff to the nature of the problem of aggression and develops their knowledge, skills, and attitudes in managing this behavior.

Agitation, and some of the techniques described for its management, have consequences beyond the episode itself. They have been associated with increased length of stay and readmission as well as more use of medication [12]. This increases the burden and management costs associated with hospitalized patients [13]. To the best of our knowledge, no systematic review has been conducted to evaluate the use of services and, consequently, the overall costs of agitation episodes and containment techniques.

The main objective of the present study was to systematically review, for the first time, the evidence on costs and service-use associated with agitation and containment strategies in adult patients with a mental illness admitted to a psychiatric hospital or psychiatric emergency services.

\section{Methods}

PRISMA guidelines for reporting systematic reviews were followed [14]. There was no review protocol.

\section{Literature search}

A systematic review of the literature was performed for studies evaluating the use of services and/or costs of states of agitation and/or aggressiveness and the use of containment measures in adult patients admitted to psychiatric hospitals and/or emergency psychiatric units. Four electronic databases were searched from inception 
to January 2014: PubMed, CINHAL, ISI Web of Knowledge, and EMBASE. The search strategy used included terms related to 1) episodes of agitation and/or containment, 2) inpatient psychiatric care and 3) use of services and/or costs. The detailed electronic search strategy is displayed in the Additional file 1: Table S1. For the hand search, the reference list of all included citations was reviewed to recover additional articles not identified in the electronic search. Researchers with expertise in the topic of interest were asked to suggest relevant studies.

\section{Inclusion criteria and study selection}

Three researchers screened, in duplicate, the articles identified in the search in two steps: by reviewing the title and abstract of the paper, and by reading the fulltext paper. To synthesize the most up-to-date evidence, only papers published in the last 15 years (1998-2014) written in English or Spanish (the languages of the reviewers) were included in the synthesis.

Regarding study design, the inclusion criteria were broad to include as much information as possible. We included any study reporting quantitative data on the use of any service and/or costs related to an episode of agitation and/or containment, independently of the study design. The studies had to include an inpatient adult population with a mental disorder admitted to a psychiatric hospital, the psychiatric service of a general hospital or a psychiatric emergency room. Studies were included if they provided information on a sample of agitated patients. Studies were excluded if they pooled the information on agitated patients with that on nonagitated patients so that information on agitated individuals could not be extracted.

\section{Quality assessment}

Due to the wide range of study designs considered in the review, it was difficult to use a structured quality scale. Furthermore, most of the published checklists and scales are used to evaluate the quality of studies assessing the effectiveness of interventions (randomized or nonrandomized controlled trials). Quality was discussed in terms of appropriateness of study design, the quality of the methodological approach and the correct presentation and discussion of results. The quality questions considered and answered for each study are presented in Table 1. Following the quality evaluation, the reviewer classified the studies into five categories ranging from low to high quality.

\section{Data abstraction}

Three reviewers used an abstraction form to extract information on the characteristics, methods and outcomes of the retrieved studies. The abstraction form included information on the study design: setting; characteristics of the study population; total sample size and size of the agitated sample; date of the study; and data related to the use of services and costs. Outcome and variability measures were extracted for the sample of agitated/contained patients and for non-agitated/non-contained patients where possible. Only a qualitative synthesis was carried out due to the scarcity of studies, considerable design differences and heterogeneity of reported outcomes.

To homogenize, cost data originally in euros $(€)$ or British pounds ( $£$ ) was converted to euros in 2014. First, all costs were updated to the reference year using each country's annual inflation rates. Subsequently, the currency was converted into euros taking into account purchasing power parity conversion factors. We used the annual inflation rates and purchasing power parity conversion factors employed by the Organization for Economic Co-operation and Development (OECD) [15].

\section{Results}

\section{Literature search and study selection}

Figure 1 shows the flow diagram of studies identified in the search and screened for inclusion. The search of electronic databases identified 719 studies and the hand search a further 81 studies. One-hundred and five studies were duplicates and 119 were published before 1998 . Of the remaining 576 studies, 526 were excluded after a review of the title and abstract and 40 following a review of the full-text paper (23 did not include information about costs or use of services; 11 did not consider a sample of agitated patients; 3 used a setting other than a psychiatric hospital or unit; and 1 considered an infant or adolescent population). Two papers [16,17] included some information about use of services but the focus of the studies was to define the types and frequency of agitation management and predictors of agitation/restraint, while information on use of services and costs was limited. One of the studies only showed the proportion of patients receiving distinct types of treatments and the proportion of patients requiring more than one drug [17]. The second study provided information on the frequency of mechanical and pharmacological restraints used separately or in combination and the duration of mechanical restraint episodes. Finally, ten papers were included in the synthesis [16].

\section{Study quality}

Table 1 shows the quality of the 10 studies included in the review [11,18-26]. Five studies were considered of high quality, 1 of moderate-high quality, 1 of moderate quality and 3 of moderate-low quality. The main reasons for receiving a "moderate-low" evaluation were as follows: missing data; missing information on relevant results; unsuitable analysis strategy or lack of 
Table 1 Quality criteria and quality of the included studies

\begin{tabular}{|c|c|c|c|c|c|c|c|c|c|c|}
\hline & $\begin{array}{l}\text { Barlow } \\
2000\end{array}$ & $\begin{array}{l}\text { Carr } \\
2008\end{array}$ & $\begin{array}{l}\text { Compton } \\
2006\end{array}$ & $\begin{array}{l}\text { Flood } \\
2008\end{array}$ & $\begin{array}{l}\text { Jaffe } \\
2009\end{array}$ & $\begin{array}{l}\text { Legris } \\
1999\end{array}$ & $\begin{array}{l}\text { Mellesdal } \\
2003\end{array}$ & $\begin{array}{l}\text { Peiró } \\
2004\end{array}$ & $\begin{array}{l}\text { Putkonen } \\
2013\end{array}$ & $\begin{array}{l}\text { Steinert } \\
1999\end{array}$ \\
\hline $\begin{array}{l}\text { 1. Are the study objectives } \\
\text { relevant and well defined? }\end{array}$ & Yes & Yes & Yes & Yes & Yes & Yes & Yes & Yes & Yes & Yes \\
\hline $\begin{array}{l}\text { 2. Are the methods of the study } \\
\text { appropriate to realize the study } \\
\text { objectives? }\end{array}$ & Yes & Yes & $\begin{array}{l}\text { Retrospective } \\
\text { study based } \\
\text { on the } \\
\text { reviews of } \\
\text { clinical charts }\end{array}$ & $\begin{array}{l}\text { The method for } \\
\text { estimating costs } \\
\text { is based on } \\
\text { interviews with } \\
\text { key personnel } \\
\text { (probability of } \\
\text { recall bias) }\end{array}$ & $\begin{array}{l}\text { Retrospective } \\
\text { study based on } \\
\text { review of clinical } \\
\text { charts }\end{array}$ & $\begin{array}{l}\text { Retrospective } \\
\text { study based on } \\
\text { review of clinical } \\
\text { charts }\end{array}$ & Yes & $\begin{array}{l}\text { Retrospective study } \\
\text { based on review of } \\
\text { clinical charts }\end{array}$ & Yes & $\begin{array}{l}\text { Retrospective } \\
\text { study based } \\
\text { on review of } \\
\text { clinical charts }\end{array}$ \\
\hline $\begin{array}{l}\text { 3. Were the data collected with } \\
\text { sufficient quality (review of } \\
\text { patient's chart, patient interview, } \\
\text { missing data...)? }\end{array}$ & Yes & Yes & Yes & Yes & Yes & $\begin{array}{l}\text { Yes. Some scales } \\
\text { had low rates of } \\
\text { inter-rater } \\
\text { agreement and } \\
\text { could not be used } \\
\text { in the analysis }\end{array}$ & Yes & $\begin{array}{l}\text { No. High rates of } \\
\text { missing data are } \\
\text { reported on } \\
\text { sociodemographic } \\
\text { and clinical } \\
\text { variables }\end{array}$ & Yes & Yes \\
\hline $\begin{array}{l}\text { 4. Was the analysis strategy } \\
\text { adequate taking into account the } \\
\text { study objectives and methods } \\
\text { (statistical methods of analysis } \\
\text { well-designed and executed, } \\
\text { data adjusted for confounding } \\
\text { variables,...)? }\end{array}$ & $\begin{array}{l}\text { The analysis } \\
\text { strategy is } \\
\text { adequate but the } \\
\text { analyses are not } \\
\text { adjusted for } \\
\text { confounding } \\
\text { variables }\end{array}$ & Yes & Yes & Yes & Yes & Yes & Yes & $\begin{array}{l}\text { The analysis } \\
\text { strategy is } \\
\text { adequate but the } \\
\text { analysis did not } \\
\text { take into account } \\
\text { missing data and } \\
\text { could be biased. }\end{array}$ & Yes & Yes \\
\hline $\begin{array}{l}\text { 5. Is the presentation of results } \\
\text { complete and of good quality } \\
\text { (all objectives are addressed, raw } \\
\text { and adjusted results are } \\
\text { presented, information on } \\
\text { variability is presented (i.e., SD, } \\
\text { SE or confidence intervals), ...)? }\end{array}$ & $\begin{array}{l}\text { All the objectives } \\
\text { are addressed } \\
\text { but only raw } \\
\text { results are } \\
\text { presented. Lacks } \\
\text { information on } \\
\text { variability }\end{array}$ & Yes & Yes & Yes & $\begin{array}{l}\text { Absence of } \\
\text { possible } \\
\text { confounding } \\
\text { issues in the } \\
\text { analyses (e.g., } \\
\text { relevant physical- } \\
\text { mental } \\
\text { comorbidities) }\end{array}$ & Yes & Yes & $\begin{array}{l}28 \% \text { of data is } \\
\text { missing for } \\
\text { important variables } \\
\text { (age, length of } \\
\text { illness) }\end{array}$ & Yes & Yes \\
\hline $\begin{array}{l}\text { 6. Are the results discussed in } \\
\text { the context of previously } \\
\text { published studies? }\end{array}$ & Yes & Yes & Yes & $\begin{array}{l}\text { The results are } \\
\text { compared only to } \\
\text { those previously } \\
\text { obtained in USA }\end{array}$ & Yes & Yes & Yes & Yes & Yes & Yes \\
\hline $\begin{array}{l}\text { 7. Are the limitations of the } \\
\text { study discussed and the results } \\
\text { discussed taking into account } \\
\text { these limitations? }\end{array}$ & $\begin{array}{l}\text { The limitations of } \\
\text { the study are not } \\
\text { adequately } \\
\text { discussed }\end{array}$ & Yes & Yes & Yes & Yes & $\begin{array}{l}\text { The limitations } \\
\text { of the study are } \\
\text { not discussed or } \\
\text { taken into } \\
\text { account when } \\
\text { drawing } \\
\text { conclusions }\end{array}$ & Yes & Yes & Yes & Yes \\
\hline $\begin{array}{l}\text { 8. Are the conclusions of the } \\
\text { study supported by the results? }\end{array}$ & Yes & Yes & Yes & Yes & Yes & Yes & Yes & Yes & Yes & Yes \\
\hline QUALITY & Low-Moderate & High & High & Moderate-High & Low-Moderate & Moderate & High & Low-moderate & High & High \\
\hline
\end{tabular}




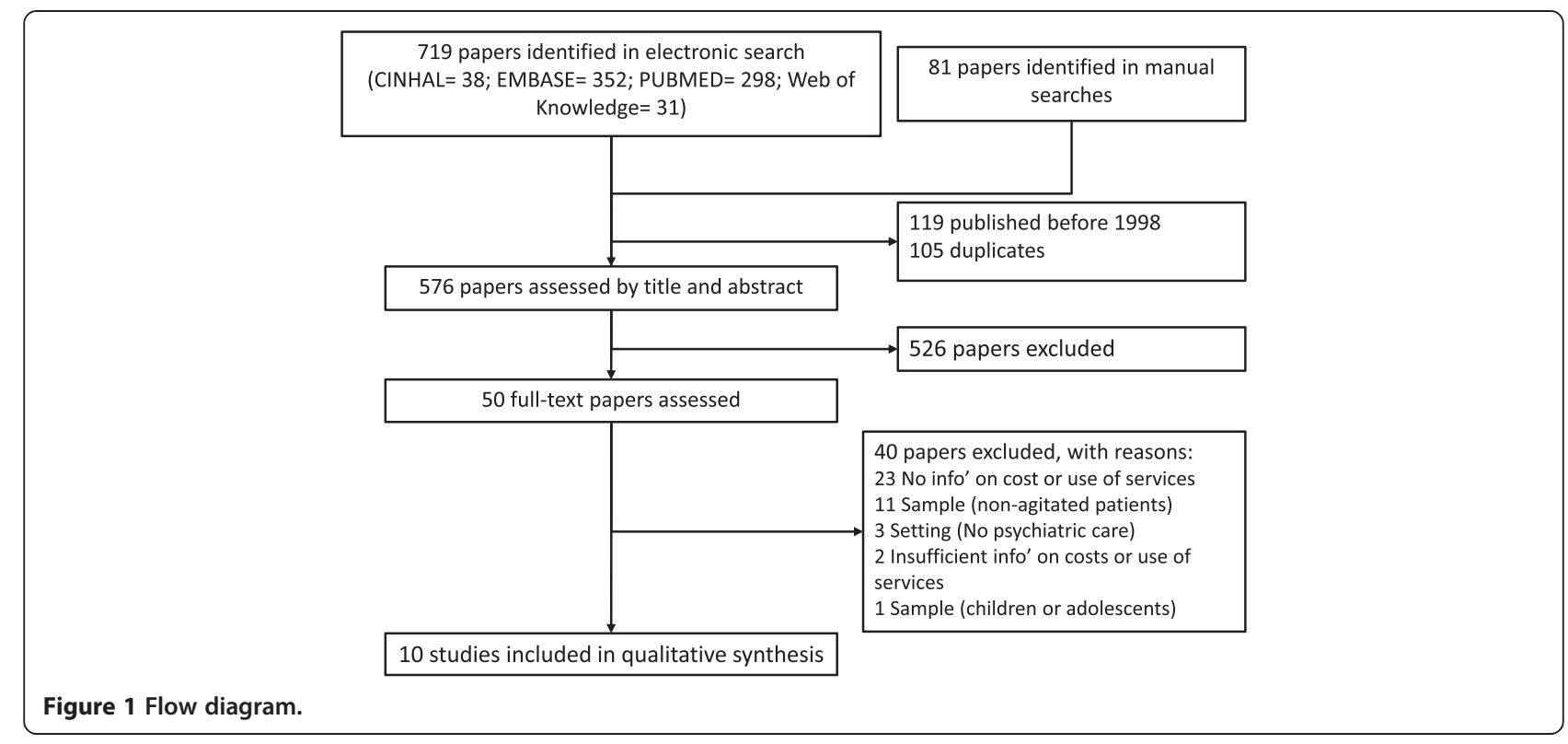

adjustment for confounding variables in the analysis; and lack of information on variability in the presentation of results.

\section{Study characteristics}

Table 2 shows the characteristics of the studies included. Most had been conducted in Australia (2) and the USA (2) while others had been carried out in Canada, Finland, Germany, Norway, Spain and the UK. The majority of the studies were retrospective cohorts based on the review of clinical charts (5) or prospective cohorts (3). One study was an epidemiological, crosssectional study based on questionnaires completed by nurses and one was a cluster-randomized controlled trial. The follow-up periods ranged from 6 months to 4 years.

The proportion of men and women was relatively balanced in all studies but one [26]. Mean age ranged from 32.4 to 41.5 years and total sample size and size of the agitated sample ranged from 85 to 3,232 and from 41 to 849 , respectively. One study presented information on overall costs of agitation [11] while nine studies presented information on the use and/or costs of specific services. Six studies compared samples of aggressive and/or agitated and non-aggressive and non-agitated patients $[18,19,21,23-25]$. These studies presented information on use of service in terms of lengths of stay (6), readmission rates (4) and cost of medication (1). Two studies assessed the impact of use of seclusion or restraint on length of stay (2) and use of medication (1) $[20,22]$. One study reported on the number of staff sick days before and after an intervention strategy to reduce the use of coercive measures [26].

\section{Impact of aggressiveness and/or agitation}

Steinert and cols. [25] conducted a retrospective database cohort study in one psychiatric hospital in Germany. The sample consisted of 96 patients showing aggressive or agitated behavior (threats of violence or violence against persons or objects) and 42 nonagitated/aggressive patients. The study evaluated the associations between aggressive behavior and length of stay and readmission. Aggressive behavior showed no association with the length of stay. However, the number of hospitalizations was significantly predicted by aggressive behavior against others $(\beta=0.16, \mathrm{p}=0.03)$ and against self $(\beta=0.19, p=0.01)$.

The prospective observational study by Barlow and colleagues [18] compared a sample of aggressive patients ("defined as [those engaging in] an act of verbal or physical aggression directed to self or others, irrespective of outcome") $(\mathrm{n}=174)$ with non-aggressive patients $(\mathrm{n}=$ 922) from three acute psychiatric units and one subacute unit in Australia. Length of stay and number of readmissions were evaluated. Mean length of stay was 24.88 (SD not reported) days in the aggressive group and 12.06 (SD not reported) days in the non-aggressive group. The difference in mean days of stay between groups was statistically significant $(\mathrm{F}=68.34 ; \mathrm{p}<0.001)$. The mean number of readmissions was 3.56 (SD not reported) and 1.75 (SD not reported) in the aggressive versus the non-aggressive sample, respectively. The study reported a statistically significant difference in the mean number of readmissions over the 18-month period for the aggressive versus non-aggressive patients ( $\mathrm{F}=$ 125.22, $\mathrm{p}<0.001)$.

Mellesdal and cols. [23] conducted a prospective observational study in a psychiatric acute ward in Norway. 
Table 2 Characteristics of the included studies

\begin{tabular}{|c|c|c|c|c|c|c|c|c|}
\hline Paper & $\begin{array}{l}\text { Country and period } \\
\text { of study (year) }\end{array}$ & Design & Setting & Diagnosis (\%) & Mean age & $\%$ of men $(\mathrm{N})$ & Total sample size & Agitated sample size \\
\hline \multirow[t]{8}{*}{ Barlow K et al. 2000 [18] } & $\begin{array}{l}\text { Australia, } 18 \text { months } \\
(1996-1997)\end{array}$ & $\begin{array}{l}\text { Prospective } \\
\text { observational } \\
\text { study }\end{array}$ & $\begin{array}{l}3 \text { acute psychiatric units } \\
\text { and } 1 \text { subacute unit }\end{array}$ & Schizophrenia (21.3) & $\begin{array}{l}37 \text { (range: } \\
13-97)\end{array}$ & $52.2(663)$ & 1,096 & 174 \\
\hline & & & & Psychotic disorder (14.0) & & & & \\
\hline & & & & Bipolar affective (7.2) & & & & \\
\hline & & & & Adjustment disorder (18.5) & & & & \\
\hline & & & & Depression (18.5) & & & & \\
\hline & & & & Personality disorder (3.0) & & & & \\
\hline & & & & Anxiety disorder (5.0) & & & & \\
\hline & & & & Other (12.4) & & & & \\
\hline \multirow[t]{6}{*}{ Carr VJ et al. 2008 [19] } & $\begin{array}{l}\text { Australia, } 12 \text { months } \\
\text { (n.a.) }\end{array}$ & $\begin{array}{l}\text { Prospective } \\
\text { observational } \\
\text { study }\end{array}$ & $\begin{array}{l}11 \text { mental health units } \\
\text { ( } 8 \text { general psychiatric } \\
\text { units, } 2 \text { high- } \\
\text { dependency units and } 1 \\
\text { specialized unit) }\end{array}$ & $\begin{array}{l}\text { Drug and alcohol } \\
\text { disorder (44.6) }\end{array}$ & 37.1 (SD 14.4) & $\begin{array}{l}55.0 \\
\text { (weighted } \\
\text { percentage) } \\
(2,210)\end{array}$ & 3,242 & $\begin{array}{l}849 \text { (Aggressive } \\
\text { incidents: 363; Less } \\
\text { serious aggressive } \\
\text { incidents: 486) }\end{array}$ \\
\hline & & & & $\begin{array}{l}\text { Schizophrenia or related } \\
\text { disorder (38.0) }\end{array}$ & & & & \\
\hline & & & & Depression (25.3) & & & & \\
\hline & & & & Personality disorder (18.9) & & & & \\
\hline & & & & Adjustment disorder (14.2) & & & & \\
\hline & & & & Bipolar disorder (14.0) & & & & \\
\hline \multirow[t]{6}{*}{ Compton MT et al. 2006 [20] } & $\begin{array}{l}\text { USA, } 7 \text { months } \\
\text { (2003-2004) }\end{array}$ & $\begin{array}{l}\text { Retrospective } \\
\text { database cohort } \\
\text { study }\end{array}$ & $\begin{array}{l}2 \text { inpatient psychiatric } \\
\text { units (a crisis } \\
\text { stabilization unit (CSU) } \\
\text { and a longer-stay milieu } \\
\text { unit (LSMU)) }\end{array}$ & $\begin{array}{l}\text { Schizophrenia or other } \\
\text { psychotic disorders (65.0) }\end{array}$ & $\begin{array}{l}\text { LSMU: } 37.4 \\
\text { (SD 12.6) } \\
\text { CSU: } 40.8 \\
\text { (SD 11.8) }\end{array}$ & $\begin{array}{l}\text { LSMU: } 40.7 \\
\text { (60), CSU: } \\
48.9 \text { (43) }\end{array}$ & $\begin{array}{l}\text { LSMU: 146; CSU: } \\
88\end{array}$ & n.a. \\
\hline & & & & Unipolar depression (15.8) & & & & \\
\hline & & & & Bipolar disorder (12.4) & & & & \\
\hline & & & & Anxiety disorders (0.9) & & & & \\
\hline & & & & $\begin{array}{l}\text { Substance-related } \\
\text { disorders (4.3) }\end{array}$ & & & & \\
\hline & & & & Other (1.3) & & & & \\
\hline Flood C et al. 2008 [13] & $\begin{array}{l}\text { United Kingdom, } \\
1 \text { year (2005) }\end{array}$ & $\begin{array}{l}\text { Epidemiological, } \\
\text { cross-sectional } \\
\text { study }\end{array}$ & $\begin{array}{l}136 \text { adult acute } \\
\text { inpatient psychiatric } \\
\text { wards }\end{array}$ & n.a. & n.a. & & n.a. & \\
\hline
\end{tabular}


Table 2 Characteristics of the included studies (Continued)

\begin{tabular}{|c|c|c|c|c|c|c|c|c|}
\hline \multirow[t]{5}{*}{ Jaffe A et al. 2009 [21] } & $\begin{array}{l}\text { USA, } 6 \text { months } \\
\text { (2005) }\end{array}$ & $\begin{array}{l}\text { Retrospective } \\
\text { database cohort } \\
\text { study }\end{array}$ & $\begin{array}{l}17 \text { state-run adult civil } \\
\text { facilities }\end{array}$ & Schizophrenia (41.4) & 41.5 (SD 13.6) & $63(257)$ & 1,673 & 415 \\
\hline & & & & Schizoaffective (31.9) & & & & \\
\hline & & & & Bipolar (10.4) & & & & \\
\hline & & & & Depression (5.7) & & & & \\
\hline & & & & Other (10.6) & & & & \\
\hline \multirow[t]{4}{*}{ Legris J et al. 1999[22] } & Canada, n.a. (n.a.) & $\begin{array}{l}\text { Retrospective } \\
\text { database cohort } \\
\text { study }\end{array}$ & $\begin{array}{l}\text { Urban general hospital } \\
\text { with two adult } \\
\text { psychiatric wards and a } \\
\text { special care unit }\end{array}$ & Schizophrenia (54) & 41 (SD 16) & $41(35)$ & 85 & 41 \\
\hline & & & & $\begin{array}{l}\text { Bipolar or schizoaffective } \\
\text { (23) }\end{array}$ & & & & \\
\hline & & & & Psychotic depression (12) & & & & \\
\hline & & & & Other (11) & & & & \\
\hline \multirow[t]{6}{*}{ Mellesdal L 2003 [23] } & $\begin{array}{l}\text { Norway, } 3 \text { years } \\
(1997-2000)\end{array}$ & $\begin{array}{l}\text { Prospective } \\
\text { observational } \\
\text { study }\end{array}$ & Psychiatric acute ward & Affective disorders (34.7) & 41.1 (SD 15.5) & $51(476)$ & 934 & 98 \\
\hline & & & & $\begin{array}{l}\text { Schizophrenic disorders } \\
(19.2)\end{array}$ & & & & \\
\hline & & & & $\begin{array}{l}\text { Alcohol/substance abuse } \\
(10.4)\end{array}$ & & & & \\
\hline & & & & Personality disorders (9.4) & & & & \\
\hline & & & & $\begin{array}{l}\text { Neurotic/stress-related } \\
\text { somatoform disorders (7.1) }\end{array}$ & & & & \\
\hline & & & & Other (19.2) & & & & \\
\hline \multirow[t]{5}{*}{ Peiró S et al. 2004 [24] } & $\begin{array}{l}\text { Spain, } 6 \text { months } \\
\text { (1999-2001) }\end{array}$ & $\begin{array}{l}\text { Retrospective } \\
\text { database cohort } \\
\text { study }\end{array}$ & $\begin{array}{l}\text { Acute inpatient units } \\
\text { from } 8 \text { general } \\
\text { hospitals and } \\
\text { psychiatric hospitals }\end{array}$ & $\begin{array}{l}\text { Schizophrenic disorders } \\
(64.0)\end{array}$ & 39.2 (SD 14.5) & $44.8(56)$ & 200 & 175 \\
\hline & & & & Affective psychosis (22.0) & & & & \\
\hline & & & & Paranoid states (4.5) & & & & \\
\hline & & & & $\begin{array}{l}\text { Other non-organic } \\
\text { psychosis (8.5) }\end{array}$ & & & & \\
\hline & & & & $\begin{array}{l}\text { Transient organic psychosis } \\
\text { (1.0) }\end{array}$ & & & & \\
\hline
\end{tabular}


Table 2 Characteristics of the included studies (Continued)

\begin{tabular}{|c|c|c|c|c|c|c|c|c|}
\hline Putkonen A et al. 2013 [26] & $\begin{array}{l}\text { Finland, } 6 \text { months } \\
\text { (2009) }\end{array}$ & $\begin{array}{l}\text { Cluster- } \\
\text { randomized } \\
\text { controlled trial }\end{array}$ & $\begin{array}{l}\text { Four high-security } \\
\text { wards for men with } \\
\text { psychotic illness. }\end{array}$ & $\begin{array}{l}\text { Psychotic illness with a } \\
\text { history of severe violence } \\
(100)\end{array}$ & $\begin{array}{l}\text { Control } \\
\text { group: } 40.0 \\
\text { (SD 10.6) } \\
\text { Intervention } \\
\text { group: } 38.4 \\
\text { (SD 10.6) }\end{array}$ & 100 & $\begin{array}{l}\text { Control group: } \\
930-1,003 \text { patient- } \\
\text { days per month } \\
\text { (38 beds) } \\
\text { Intervention } \\
\text { group: } 1,306-1,400 \\
\text { patient-days per } \\
\text { month ( } 50 \text { beds) }\end{array}$ & n.a. \\
\hline \multirow[t]{4}{*}{ Steinert T et al. 1999 [25] } & $\begin{array}{l}\text { Germany, } 4 \text { years } \\
(1990-1993)\end{array}$ & $\begin{array}{l}\text { Retrospective } \\
\text { database cohort } \\
\text { study }\end{array}$ & Psychiatric hospital & $\begin{array}{l}\text { Paranoid type } \\
\text { schizophrenia (78.9) }\end{array}$ & 32.4 (SD 12.7) & $55.8(77)$ & 138 & 96 \\
\hline & & & & $\begin{array}{l}\text { Schizoaffective disorder } \\
(15.9)\end{array}$ & & & & \\
\hline & & & & $\begin{array}{l}\text { Accompanying substance } \\
\text { abuse (29.7) }\end{array}$ & & & & \\
\hline & & & & $\begin{array}{l}\text { Accompanying somatic } \\
\text { disease }(21.0)\end{array}$ & & & & \\
\hline
\end{tabular}


The study compared patients with $(\mathrm{n}=98)$ and without $(\mathrm{n}=836)$ aggressive incidents ("behavior intended to cause bodily harm or physical injury [to] other persons and as verbal and physical threats of inflicting bodily harm upon others") and compared mean length of stay and mean number of readmissions between groups. The mean length of stay for aggressive patients was significantly higher than for non-aggressive patients (32.6 vs 9.7, $\mathrm{p}<0.01$ ). The mean number of readmissions was also significantly higher than for non-aggressive patients $(2.5$ vs $1.5, \mathrm{p}<0.01)$ with a significantly higher proportion of readmissions of aggressive patients $\left(\chi^{2}=\right.$ 53.2, $\mathrm{p}<0.001)$.

Peiró and cols. [24] conducted a retrospective cohort study with databases from acute inpatient units from 8 general hospitals and psychiatric hospitals. The study evaluated the relationship between the presence of aggressiveness and/or agitation ("defined as an annotation in the medical record of this symptom") $(\mathrm{n}=175)$ and not presenting aggressiveness and/or agitation $(n=25)$, and the length of stay and the cost of medication. The mean length of stay in the group of patients presenting aggressiveness and/or agitation was 21.87 days (95\% CI $18.88,24.87$ ) while it was 21.08 days (95\% CI 14.52, 27.64) in the patients not presenting aggressiveness and/ or agitation. No statistically significant association between aggressiveness and/or agitation and length of stay was observed. Mean antipsychotic drug cost was $96.76 €$ (95\% CI 72.5€, 121.0€) for aggressive and/or agitated patients and $23.47 €(95 \%$ CI $5.0 €, 42.0 €)$ for non-aggressive and non-agitated individuals. The difference in the extra mean cost of treatment was statistically significant only in the unadjusted analysis $(\mathrm{p}<0.05)$ while the updated mean extra cost of the treatment of agitated patients was $50.97 €(95 \% \mathrm{CI}-28.1 €, 130.0 € ; \mathrm{p}=0.171)$ in the adjusted analysis.

The study by Carr and cols. [19] was a prospective observational study including a sample of 3,242 patients from 11 mental health units in Australia. The study evaluated two groups of patients: patients involved in serious aggressive incidents ("i.e., involving physical contact or a definite intention to inflict harm") ( $\mathrm{n}=363)$ and patients involved in less serious aggressive incidents ("i.e., verbal threats or demands without a plan to inflict harm") $(n=486)$. The study evaluated the association between aggressive status and length of stay, and number of readmissions. Mean length of stay was 27.34 (SD 28.61) days for patients involved in aggressive incidents and 14.38 (SD 17.57) days for those not involved. In patients involved in less serious aggression and those not involved in any aggressive incidents, mean length of stay was 23.30 (SD 23.30) and 14.54 (SD 18.90) days, respectively. Reported serious aggressive incidents were strongly associated with length of stay both in the unadjusted and adjusted analyses, with a mean of 12.96 and 11.68 extra days $(\mathrm{p}<0.001)$, respectively. This was also the case for less serious aggression, with a mean of 8.77 and 8.28 extra days in the unadjusted and adjusted analyses, respectively $(\mathrm{p}<$ 0.001 ). The proportion of readmitted patients within 28 days after discharge was higher in the group of patients involved in serious aggressive incidents $(21.6 \%)$ than in the group of those not involved (14.8\%), both in the unadjusted (OR $1.59 \mathrm{p}<0.001$ ) and adjusted analyses (OR $1.74 \mathrm{p}<0.001)$. In the group of patients involved in less serious aggressive incidents, readmission occurred in $19.3 \%$ compared with $14.9 \%$ in the group of patients not involved. However, this difference was not statistically significant in either the adjusted or unadjusted analysis.

Jaffe and cols. [21] reviewed, in a retrospective cohort study, the database of 17 state-run adult civil facilities. They assessed length of stay (time to discharge) in a sample of 415 agitated patients ("patients receiving an intramuscular "stat" medication order for the presumed treatment of agitation") and 1,258 nonagitated patients ("patients who did not have an order for an 'agitation stat"). The adjusted odds ratio for discharge at 6 months was $0.63(95 \%$ CI $0.46,0.86, p=$ 0.004 ) for agitated compared with non-agitated patients. Median time to discharge in the agitated and non-agitated sample was 164 days (95\% CI 129, 199) and 110 days $(95 \%$ CI 100, 120), respectively, with a relative risk difference for discharge within the first 30 days of 0.55 (95\% CI 0.33, 0.90).

Putkonen and cols. [26] conducted a clusterrandomized trial in 4 wards in Finland to evaluate the effectiveness of preventing coercive measures without violence in high-security wards for males with schizophrenia and a history of severe violence. The program was implemented in 2009. One of the outcome measures was length of staff sick-leave time after a patient-to-staff injury. The mean duration of sick leave was 8.8 days per injury in 2007, 1.6 days per injury in 2008 and 1.8 days per injury in 2009.

\section{Impact of seclusion and/or restrain}

Legris and cols. [22] conducted a retrospective cohort study using the databases of one urban general hospital with two adult psychiatric wards and a special care unit comparing cohorts of secluded (41) and non-secluded (44) patients. Mean length of hospital stay was 41 (SD 31.0) days for secluded patients and 29 (SD 24.8) days for non-secluded patients. This difference did not reach statistical significance $(\mathrm{p}=0.053)$. There was a higher mean daily drug dose (in chlorpromazine equivalents) in the secluded sample $(748.5 \mathrm{mg})$ compared with the nonsecluded sample $(464.8 \mathrm{mg})(\mathrm{p}=0.036)$. 
The study by Compton and cols. [20] was a retrospective database cohort study using data from two inpatient psychiatric units in the USA: a crisis stabilization unit (CSU) and a longer-stay milieu unit (LSMU). The study included 88 patients from the CSU and 146 patients from the LSMU. The use of seclusion or restraint was not associated with a longer length of stay among patients admitted to the CSU (Beta $=1.22, \mathrm{SE}=0.71, \mathrm{p}=$ 0.09 ) but it was among patients admitted to the LSMU (Beta $(\log 10)=0.16, \mathrm{SE}=0.01, \mathrm{p}<0.01)$, with a mean of 1.45 (95\% CI 1.21, 1.73) extra days of stay.

\section{Costs of conflictive behaviors and containment}

One study conducted in the UK evaluated the national costs of conflictive behaviors and containment in psychiatric acute units in 2005 using an epidemiological, crosssectional study [11]. Table 3 shows the aggregated and updated costs per ward for the conflictive behavior and containment events considered in the study. Conflictive behavior included verbal abuse; aggression towards objects or persons; self-harm; refusing to follow indications; use of alcohol or drugs; absconding; and refusing medicines. The total cost per ward estimated for the year 2014 of all conflictive behavior was $€ 182,616$ while the total national cost was 91 million euros. The containment events included use of medication; referral to intensive care units; observation; show of force, restraint and seclusion; and time out. The total containment costs per ward were $€ 182,616$ while national containment costs reached 133 million euros. Verbal abuse, aggression (to objects, others and self) accounted for an elevated proportion of the costs of conflictive behavior $(€ 47,529$ per ward). The most expensive containment event was intermittent observation and special observation at $€ 204,072$ per ward.

\section{Discussion}

Six of the 8 studies included in our review that evaluated length of stay found a positive association between length of stay and agitation states or containment [18-23], while all of the studies that evaluated the probability of readmission reported a statistically significant association with aggressiveness or agitation [18,19,23,25]. Two studies examined the use of drugs in agitated and secluded patients by comparing mean daily medication dose and mean cost of treatment $[22,24]$. These studies found that medication doses and costs were associated with seclusion and agitation, respectively.

The results of our systematic review can be summarized as follows: first, the evidence on use of services and costs of agitation and containment in inpatient psychiatric care was scant. Only ten studies from the last 15 years provide information on use of services and costs, and very few services were evaluated. Second, the nine study designs differed widely, complicating between-study comparisons. Methodological quality was high or moderately-high in 5 of the 9 studies. Third, according to the retrieved studies, aggressiveness, agitation and containment measures are associated with increased services and costs (in terms of length of stay, higher readmission rates and increased medication consumption). Evidence on readmission and use of medicines is inconclusive. However, the studies that did not identify a statistically significant difference in length of stay between agitated/aggressive and non-agitated/aggressive patients were those using a higher threshold for behavior defined as agitated or aggressive. One study reported

Table 3 Aggregated conflict behaviors and containment event updated annual costs [and original costs (11)]

\begin{tabular}{|c|c|c|}
\hline Conflict behaviors costs & Cost per ward & Cost nationally \\
\hline Verbal abuse, aggression towards objects and physical assault & $47,529 €[£ 37,785]$ & $23,764,980 €[£ 18,892,816]$ \\
\hline Self harm & $10,284 €[£ 8,176]$ & $5,142,434 €[£ 4,088,161]$ \\
\hline Smoking in non-smoking areas or refusing to eat, drink, wash, get up, go to bed or see workers & $55,319 €[£ 43,978]$ & $27,659,246 €[£ 21,988,701]$ \\
\hline Alcohol or drug use & $11,565 €[£ 9,194]$ & $5,782,210 €[£ 4,596,773]$ \\
\hline Attempts to abscond or absconding & $31,807 €[£ 25,286]$ & $15,903,323 €[£ 12,642,912]$ \\
\hline Refused regular or Pro Re Nata medicines or demand of Pro Re Nata medicines & $26,112 €[£ 20,759]$ & $13,055,998 €[£ 10,379,330]$ \\
\hline Cost of all conflict behavior & $182,616 €[£ 145,177]$ & $91,308,194 €[£ 72,588,694]$ \\
\hline Containment events costs & Cost per ward & Cost nationally \\
\hline Given Pro Re Nata or intramuscular medicines & $28,916 €[£ 22,988]$ & $14,457,777 €[£ 11,493,724]$ \\
\hline Sent to Intensive Care Unit or Intermediate Care Area & $2,549 €[£ 2,026]$ & $1,274,497 €[£ 1,013,207]$ \\
\hline Intermittent and constant special observation & $204,072 €[£ 162,234]$ & $102,035,487 €[£ 81,116,737]$ \\
\hline Show of force, manual restraint and seclusion & $28,518 €[£ 22,671]$ & $14,259,142 €[£ 11,335,812]$ \\
\hline Time out & $3,015 €[£ 2,397]$ & $1,507,595 €[£ 1,198,516]$ \\
\hline Cost of all containment events & $267,069 €[£ 212,316]$ & $133,534,500 €[£ 106,157,997]$ \\
\hline
\end{tabular}


that the mean duration of staff sick leave after an incident of patient aggression ranged from 1.6 to 8.8 days per injury but the study did not compare samples of agitated and non-agitated patients. Finally, only one study focused on the annual economic consequences of conflictive behaviors and containment events; found to be over $€ 91$ and $€ 133$ million, respectively, in the UK.

As shown in previous reviews [27], several factors, particularly context and patient characteristics, influence seclusion. A similar conclusion can be inferred regarding restraint. In this area of research, the famous "chicken and egg dilemma" remains unresolved. There appear to be various possibilities that are not mutually exclusive: (1) higher agitation might be a "causal" factor of an increased length of stay because it may itself be a sign of illness severity; (2) a longer stay in an aversive or restrictive environment may cause increased levels of agitation, aggression, or absconding; or (3) the significant relationship between the agitation and length-of-stay variables might be mediated by unknown variables linked to the context where this relationship is observed. Future studies should focus on the causal association between these variables and go beyond correlational analysis.

Most of the retrieved studies focused on direct healthcare costs from the perspective of the hospital and did not take into account other costs such as those related to patient and staff productivity losses. Furthermore, most of the studies only evaluated whether agitated or aggressive behaviors were associated with increased use of some services and/or costs but did not quantify the costs. This might suggest that the optimal design for measuring the costs of agitation is a cost-of-illness study [28] that takes into account its prevalence. Ideally, such a study should consider all relevant services and costs, including indirect costs such as those related to premature death. Intangible costs related to patient suffering are also relevant although measuring them is troublesome. Differences exist between countries in use and duration of containment so multicenter international studies should be encouraged. This would facilitate better understanding of the issue and allow informed decision-making regarding the efforts required to prevent and manage these episodes. With the available evidence, the optimal strategy appears to be a reduction of special observation events.

To allow comparisons between studies, it is essential to reach consensus on the definition and operational criteria of what is considered to be an agitation episode, as well as a standard definition and taxonomy for the related care interventions. The study by Flood et al. [13] considers conflictive behaviors and includes costs resulting from a patient refusing to eat, drink or wash, whether or not this ends in verbal abuse or aggression. A number of studies considered aggressiveness or episodes of aggression while others focused on more severe cases such as secluded patients. This adds heterogeneity to the study results. Some instruments for quantifying the nature and frequency of aggressive behaviors exist such as the Report Form for Aggressive Episodes (REFA) [29] or the Staff Observation Aggression Scale [30]. It is vital to bear the nature of the case in mind when conducting a cost-of-illness study [28]. However, a cost-of-illness study will only provide information on the extent of the problem in terms of impact on healthcare resources and labor productivity [28]. Economic evaluations of interventions designed to improve inpatient care and reduce costs resulting from aggressiveness and agitation must be conducted to support their implementation.

Rates of containment and restraint could be relevant indicators of both the quality of individual services and the quality and performance of the mental health system as a whole. However, to be effectively used for evidenceinformed policy, these rates need to be contextualized in relation to the number of residential services available for acute care, the placement capacity in the system, outpatient acute services and other data on service availability. Even when national data are available (e.g., Finland and Norway) [8], these may not indicate system quality unless full information is available on the number of beds for acute care in the system. Taking the Roemer effect into account (hospitalization depends on bed availability more than on severity of illness) [31], higher rates of restraint and constraint could be due to greater availability of acute beds in the system and not to lower quality of acute care. Unfortunately, none of the published studies on constraint and containment provided comparable information on service availability. Therefore, health-action categorization systems, such as the International Classification of Health Interventions (ICHI), should be complemented with the use of standard classifications of acute care services such as that provided in the context of long-term care by the DESDE-LTC system [32]. Future studies should provide more detailed information, especially on service availability at the local or national level [33].

The effectiveness of seclusion and restraint techniques is not supported by empirical evidence [3,4]. Indeed, the reduction or elimination of these procedures should be associated with savings and cost-benefits by reducing staff and patient injuries, workers' compensation costs and claims, liability savings, lost staff time and associated expenses, staff turnover, and staff absenteeism. Shorter lengths of stay and a decrease in rehospitalization rates are also very important benefits [34]. Moreover, seclusion and restraint can have severe psychological and physical consequences for all individuals involved [35], a high level of patient-perceived coercion can decrease 
treatment satisfaction [36] and being restrained can even decrease the likelihood of attending further follow-up and treatment sessions [37]. A body of work has been developed with the aim of replacing these techniques with more adaptive strategies [38,39]. One recent approach is the de-escalation intervention described in the BETA project [40]. Another interesting intervention, when de-escalation techniques have failed, is the TRECSAVE study [41] where researchers suggest the least restrictive option for aggressive/agitated psychotic patients when admitted to emergency rooms. Nonetheless, although these new alternatives seem effective in reducing seclusion and restraint, some important issues remain unexplored: can these new interventions increase quality of life and wellbeing? Are these cost-saving interventions? Can they decrease length of stay and use of psychiatric services?

Our results should be interpreted with the following limitations in mind. We only considered studies conducted in an adult population receiving inpatient care and only included papers published in the last fifteen years. This increases the homogeneity and current relevance of the results but limits extrapolation to other populations and contexts. Heterogeneity of the definitions of agitation and aggressive behaviors used in all the studies included could increase variability of results and hamper comparisons. We did not search the grey literature and only included papers written in English or Spanish. However, we searched four distinct electronic databases and conducted an intensive manual search. In addition, we accepted any study design to identify all the relevant literature on the topic. The scale used to evaluate quality was not a structured-quality scale but enabled us to score and compare research using various study designs. Study selection, data extraction and quality assessment were done in duplicate to minimize bias.

\section{Conclusions}

Agitation and/or aggressiveness are relevant components of hospital costs but the evidence on expenditure is scarce. The absence of consensus on the definition of agitated and/or aggressive behavior, together with the heterogeneous evaluation methods, limit our capacity to draw conclusions. Furthermore, the studies retrieved focused on use of services and/or costs from the perspective of the hospital or psychiatric service and only one study evaluated the impact of agitation and/or aggressive behavior on indirect costs. The present systematic review has identified some gaps in this area of research that need to be addressed. Commonly accepted terminology and taxonomy is required and more studies are needed, particularly with respect to causal relationships and the issue of how to standardize study designs to allow international comparison of results. It is to be expected that different types of restraint incur different costs, which should also be evaluated. Interventions aiding the management of aggressive incidents should be coded and classified. To serve as reliable performance and quality indicators, contextual information on service availability should also be provided.

\section{Additional file}

Additional file 1: Table S1. Detailed search strategy in the four electronic databases.

\section{Competing interests}

Dr. MRV, Dr. JVL, Mr. JMO, Dr. LSC and Dr. ASB declare no conflicts of interest. Mr. AG is a full time Ferrer employee.

\section{Authors' contributions}

MRV participated in the study concept and designs, acquisition of data, synthesis and interpretation of data and drafting and critical revision of the manuscript. JVL participated in the acquisition of data, synthesis and interpretation of data and drafting and critical revision of the manuscript. JMO participated in the interpretation of data and critical review of the manuscript for important intellectual content. LSC participated in the interpretation of data and drafting and critical revision of the manuscript. AG participated in the acquisition of data, interpretation of data and critical review of the manuscript for important intellectual content. ASB participated in the acquisition of data, synthesis and interpretation of data and drafting and critical revision of the manuscript. All authors read and approved the final manuscript.

\section{Acknowledgements}

The research was conducted with the support of an unrestricted grant from Ferrer. The funder had no influence on the decisions concerning the study design, data collection and analysis, or preparation of the manuscript.

\section{Author details}

${ }^{1}$ Fundació Sant Joan de Déu, Esplugues de Llobregat, Spain. ${ }^{2}$ Primary Care Prevention and Health Promotion Research Network (RedIAPP), Barcelona, Spain. ${ }^{3}$ School of Pharmacy, Universitat de Barcelona, Barcelona, Spain. ${ }^{4}$ Open University of Catalonia (UOC), Barcelona, Spain. ${ }^{5}$ Parc Sanitari Sant Joan de Déu, Sant Boi de Llobregat, Spain. ${ }^{6}$ Centre for Disability Research and Policy, Faculty of Health Sciences, and Mental Health Policy Unit, Brain and Mind Research Institute, University of Sydney, Sydney, Australia.

${ }^{7}$ Scientific Area, Ferrer, Barcelona, Spain. ${ }^{8}$ Research \& Development Unit, Parc Sanitari Sant Joan de, 22 Déu. C/ Dr. Antoni Pujadas 42, 08830 Sant Boi de Llobregat, Barcelona, Spain.

Received: 22 October 2014 Accepted: 19 February 2015

Published online: 04 March 2015

\section{References}

1. Day RK. Psychomotor agitation: poorly defined and badly measured. J Affect Disord. 1999;55:89-98.

2. Dean K, Walsh E, Morgan C, Demjaha A, Dazzan P, Morgan K, et al. Aggressive behaviour at first contact with services: findings from the AESOP first episode psychosis study. Psychol Med. 2007;37:547-57.

3. National Institute for Health and Clinical Excellence (NICE). Violence: The short-term management of disturbed/violent behaviour in in-patient psychiatric settings and emergency departments. London: NICE; 2005.

4. Sailas E, Fenton M. Seclusion and restraint for people with serious mental illnesses. The Cochrane Database of Systematic Reviews. 2000;1:CD001163. Review updated in 2012.

5. Muralidharan S, Fenton M. Containment strategies for people with serious mental illness. Cochrane Database Systematic Rev. 2006;19:CD002084.

6. Australian Institute of Health and Welfare. Development of a prototype Australian Mental Health Intervention Classification: a working paper. Cat. no. HSE 130. Canberra: AlHW; 2013. 
7. American Medical Association (AMA). Current Procedural Terminology (CPT). Chicago, USA: 2013.

8. Stewart D, Bowers L, Simpson A, Ryan C, Tziggili M. Manual restraint of adult psychiatric inpatients: a literature review. J Psychiatr Ment Health Nurs. 2009;16:749-57.

9. Steinert T, Lepping P, Bernhardsgrütter R, Conca A, Hatling T, Janssen W, et al. Incidence of seclusion and restraint in psychiatric hospitals: a literature review and survey of international trends. Soc Psychiatry Psychiatr Epidemiol. 2010;45:889-97.

10. Raboch J, Kalisová L, Nawka A, Kitzlerová E, Onchev G, Karastergiou A, et al. Use of coercive measures during involuntary hospitalization: findings from ten European countries. Psychiatr Serv. 2010;61:1012-7.

11. Kynoch $\mathrm{K}, \mathrm{Wu} C$, Chang AM. Interventions for preventing and managing aggressive patients admitted to an acute hospital setting: a systematic review. Worldviews Evid Based Nurs. 2011;8:76-86.

12. Zhang J, Harvey C, Andrew C. Factors associated with length of stay and the risk of readmission in an acute psychiatric inpatient facility: a retrospective study. Aust N Z J Psychiatry. 2011;45:578-85.

13. Flood C, Bowers L, Parkin D. Estimating the costs of conflict and containment on adult acute inpatient psychiatric wards. Nurs Econ. 2008;26:325-30.

14. Knobloch K, Yoon U, Vogt PM. Preferred reporting items for systematic reviews and meta-analyses (PRISMA) statement and publication bias. J Craniomaxillofac Surg. 2011;39:91-2.

15. Organization for Economic Co-operation and Development. [http://www. oecd.org/]

16. Knutzen M, Bjorkly S, Eidhammer G, Lorentzen S, Helen Mjøsund N, Opjordsmoen S, et al. Mechanical and pharmacological restraints in acute psychiatric wards-why and how are they used? Psychiatry Res. 2013;209:91-7.

17. Pascual JC, Madre M, Puigdemont D, Oller S, Corripio I, Díaz A, et al. Estudio naturalístico: 100 episodios de agitación psicomotriz consecutivos en urgencias psiquiátricas. Actas Esp Psiquiatr. 2006;34:239-44.

18. Barlow K, Grenyer B, Ilkiw-Lavalle O. Prevalence and precipitants of aggression in psychiatric inpatient units. Australian New Zealand J Psychiatry. 2000;34:967-74.

19. Carr VJ, Lewin TJ, Sly KA, et al. Adverse incidents in acute psychiatric inpatient units: rates, correlates and pressures. Aust N Z J Psychiatry. 2008;42:267-82.

20. Compton MT, Craw J, Rudisch BE. Determinants of inpatient psychiatric length of stay in an urban county hospital. Psychiatric Q. 2006;77:173-88.

21. Jaffe A, Levine J, Citrome L. "Stat" medication administration predicts hospital discharge. Psychiatric Q. 2009;80:65-73.

22. Legris J, Walters M, Browne $G$. The impact of seclusion on the treatment outcomes of psychotic in-patients. J Adv Nurs. 1999;30:448-59.

23. Mellesdal L. Aggression on a psychiatric acute ward: a three-year prospective study. Psychol Rep. 2003;92:1229-48.

24. Peiró S, Gomez G, Navarro M, Guadarrama I, Rejas J, Psychosp Group. Length of stay and antipsychotic treatment costs of patients with acute psychosis admitted to hospital in Spain. Description and associated factors. The psychosp study. Soc Psychiatry Psychiatr Epidemiol. 2004;39:507-13.

25. Steinert T, Wiebe C, Gebhardt RP. Aggressive behavior against self and others among first-admission patients with schizophrenia. Psychiatr Serv. 1999:50:85-90.

26. Putkonen A, Kuivalainen S, Louheranta O, Repo-Tiihonen E, Ryynänen OP, Kautiainen $\mathrm{H}$, et al. Cluster-randomized controlled trial of reducing seclusion and restraint in secured care of men with schizophrenia. Psychiatr Serv. 2013;64:850-5.

27. van der Merwe M, Bowers L, Jones J, Muir-Cochrane E, Tziggili M. Seclusion: a literature review. London: City University London; 2009.

28. Larg A, Moss JR. Cost-of-illness studies: a guide to critical evaluation. Pharmacoeconomics. 2011;29:653-71.

29. Bjorkly S. Interrater reliability of the report form for aggressive episodes in group ratings. Percept Mot Skills. 1998;87:1405-6.

30. Nijman HLI, Murs P, Merckelbach HLGJ, Palmstierna T, Wistedt B, Vos AM, et al. The staff observation aggression scale-revised (SOAS-R). Aggress Behav. 1999:25:197-209.

31. Delamater PL, Messina JP, Grady SC, WinklerPrins V, Shortridge AM. Do more hospital beds lead to higher hospitalization rates? a spatial examination of Roemer's Law. PLoS One. 2013;8:e54900.

32. Salvador-Carulla L, Alvarez-Galvez J, Romero C. Evaluation of an integrated system for classification, assessment and comparison of services for long-term care in Europe: the eDESDE-LTC study. BMC Health Serv Res. 2013;13:218
33. Fernandez A, Salinas-Perez JA, Gutierrez-Colosia MR, Prat-Pubill B, Serrano-Blanco A, Molina C, Jorda E, Garcia-Alonso CR, Salvador-Carulla L. Use of an integrated atlas of mental health care for evidence informed policy in Catalonia (Spain). Epidemiol Psychiatr Sci. 2014: 1-13 (electronic publication).

34. Chan J, LeBel J, Webber L. The dollars and sense of restraints and seclusion. J Law Med. 2012;20:73-81.

35. Knox DK, Holloman Jr GH. Use and avoidance of seclusion and restraint: consensus statement of the american association for emergency psychiatry project Beta seclusion and restraint workgroup. West J Emerg Med. 2012;13:35-40.

36. Katsakou C, Bowers L, Amos T, Morriss R, Rose D, Wykes T, et al. Coercion and treatment satisfaction among involuntary patients. Psychiatr Serv. 2010;61:286-92.

37. Currier GW, Walsh P, Lawrence D. Physical restraints in the emergency department and attendance at subsequent outpatient psychiatric treatment. J Psychiatr Pract. 2011;17:387-93.

38. Gaskin CJ, Elsom SJ, Happell B. Interventions for reducing the use of seclusion in psychiatric facilities: review of the literature. Br J Psychiatry. 2007;191:298-303.

39. Scanlan JN. Interventions to reduce the use of seclusion and restraint in inpatient psychiatric settings: what we know so far a review of the literature. Int J Soc Psychiatry. 2010;56:412-23.

40. Richmond JS, Berlin JS, Fishkind AB, Holloman Jr GH, Zeller SL, Wilson MP, et al. Verbal De-escalation of the agitated patient: consensus statement of the american association for emergency psychiatry project BETA De-escalation workgroup. West J Emerg Med. 2012;13:17-25.

41. Huf G, Coutinho ES, Adams CE. Physical restraints versus seclusion room for management of people with acute aggression or agitation due to psychotic illness (TREC-SAVE): a randomized trial. Psychol Med. 2012;42:2265-73.

\section{Submit your next manuscript to BioMed Central and take full advantage of:}

- Convenient online submission

- Thorough peer review

- No space constraints or color figure charges

- Immediate publication on acceptance

- Inclusion in PubMed, CAS, Scopus and Google Scholar

- Research which is freely available for redistribution 